\title{
Kinerja Keuangan Perusahaan Terhadap Penetapan Tingkat Sewa Obligasi Syariah Ijarah di Indonesia
}

\author{
Indah Yuliana \\ Fakultas Ekonomi UIN Maliki Malang \\ Jl. Gajayana No. 50 Malang, Telepon (0341) 558881, Fax (0341) 558881, \\ E-mail: indah_yuliana74@yahoo.co.id
}

\begin{abstract}
During the period of January to July 2008, the establishment of corporate sukuk has reached $12,5 \%$ from a total is suance of corporate bonds or at Rp. 1,62 trillion. This amount has exceeded the total sukuk issuance during 2007 which amounted to Rp. 1.03 trillion. In fact skim ijarah (rents) in value is prospective for the I'ssuer intends to issue Islamic bonds. Although ijarah Islamic bond appeared after 2 years of Islamic bonds mudarobah.. Performance and risks faced by companies in influenced by internal and external factors. Financial report is one tool to report the position of the company at a particular point in time during one period. The value of the financial statements lies in the report can be used to evaluated company's current performance and predict future from the stand point of management, financial statement analysis will be useful to help anticipate the future and as starting point for planning steps that will improve company performance in the future. The research objective was to see the influence of the company's financial performance against the Islamic bond lease. Research sites are in PT Kustodian sentral efek Indonesian. This research is a type of quantitative research.
\end{abstract}

Key word: Ijarah Obligasi Syariah, ratio rata-rata, ratio manfaat, ratio berjalan, pengambil alihan asset

Obligasi syariah merupakan instrumen baru yang mewarnai pasar modal Indonesia sejak tahun 2002. Pionernya adalah PT Indosat yang telah meluncurkan obligasi syariah senilai Rp 175 miliar. Langkah ini kemudian diikuti oleh perusahaan yang lain. Obligasi yang terbit pada tahun 2004 dan 2005 sebagian besar mulai menggunakan akad ijarah. Sedangkan obligasi yang terbit pada tahun pertama 2002 dan 2003 menggunakan akad mudharabah. Walaupun obligasi syariah ijarah muncul setelah 2 tahun dari obligasi syariah mudharabah, obligasi syariah ijarah ini lebih banyak diminati terbukti sampai pada tahun 2010 ini terdapat 36 obligasi syariah ijarah yang telah diterbitkan sedangkan obligasi syariah mudarabah hanya 10. Pada tahun 2005 ada 18 emisi obligasi dengan nilai Rp. 2,2 triliun atau sekitar dua persen dari total obligasi nasional. Saat ini market share obligasi syariah baru sekitar 3\% dari total pasar obligasi korporasi senilai 
Rp 60 triliun-an. Prospeknya sangat baik seiring berkembangnya lembaga-lembaga keuangan investasi syariah. Menurut investor skim ijarah (sewa) dinilai cukup prospektif bagi para emiten yang berniat untuk menerbitkan obligasi syariah, skim ini dalam beberapa hal sangat menguntungkan dari pada obligasi syariah mudharabah (bagi hasil). Akad-akad obligasi syariah yang diterapkan di Indonesia yakni obligasi syariah dengan menggunakan akad mudharabah dan akad ijarah. Terdapat perbedaan yang mendasar diantara kedua akad tersebut. Pada obligasi syariah dengan akad mudharabah, pengusaha bertindak sebagai wakil pemilik modal, dan jika pengusaha memperoleh keuntungan maka pengusaha bertindak sebagai rekan pemilik modal, sehingga keuntungan tersebut harus dibagikan sesuai dengan prinsip musyarokah yang mengharuskan adanya bagi hasil yang adil antara pengkongsian. Obligasi syariah mudharabah memberikan return dengan penggunaan term indicative/expected return karena bersifat floating dan tergantung pada kinerja pendapatan yang dibagihasilkan. Sedangkan return pada obligasi syariah dengan akad ijarah yakni menggunakan akad atau sistem sewa, sehingga besar return yang diberikan sama sepanjang waktu atau tetap selama obligasi berlaku. Obligasi syariah telah menjadi alternatif bagi dunia usaha untuk pendanaan halal jangka panjang.

Kinerja dan risiko yang dihadapi oleh perusahaan dipengaruhi oleh faktor internal dan eksternal perusahaan (Samsul, 2006:200). Laporan keuangan merupakan salah satu alat untuk melaporkan posisi perusahaan pada satu titik waktu tertentu selama satu periode. Nilai dari laporan keuangan terletak pada bahwa laporan tersebut dapat digunakan untuk mengevaluasi kinerja perusahaan saat ini dan meramalkan kondisi masa depan. Dari sudut pandang manajemen, analisis laporan keuangan akan bermanfaat untuk membantu mengantisipasi kondisi-kondisi di masa depan maupun sebagai titik awal untuk melakukan perencanaan langkah-langkah yang akan meningkatkan kinerja perusahaan di masa dating. Analisis laporan keuangan umumnya dimulai dengan sekumpulan rasio keuangan yang dirancang untuk mengungkapkan kekuatan dan kelemahan dari sebuah perusahaan dibandingkan dengan perusahaan-perusahaan yang lain dalam industri yang sama, dan untuk menunjukkan apakah posisi keuangannya selama ini telah membaik atau memburuk. Terdapat beberapa rasio keuangan antara lain yakni rasio likuiditas, rasio menejemen aktiva, rasio manejemen utang, rasio profitabilitas, dan rasio nilai pasar. 
Beberapa peneliti yang telah meneliti mengenai obligasi, yaitu Farida Ika, 2006 meneliti Tingkat Return Obligasi Syariah Mudharabah dan Ijarah di Indonesia. Krisnilasari, 2007, meneliti Pengaruh Likuiditas Obligasi, Coupon Dan Jangka Waktu Jatuh Tempo Obligasi Terhadap Perubahan Harga Obligasi. Yasmine Meitasari dan Emelia, 2007 meneliti Pengaruh Suku Bunga dan Rasio-Rasio Keuangan Terhadap Return Obligasi Korporasi. Yuliana Indah, 2008 meneliti Pengaruh Inflasi dan Tingkat Suku Bunga SBI Terhadap Return Obligasi Syariah Mudharabah dan Ijarah Di Indonesia. Dari uraian diatas peneliti ingin melihat pengaruh dari kinerja keuangan perusahaan terhadap tingkat sewa obligasi syariah ijarah di Indonesia.

\section{Kinerja Keuangan Rasio Keuangan}

Laporan keuangan akan melaporkan posisi perusahaan pada satu titik waktu tertentu maupun operasinya selama periode tertentu di masa lalu. Akan tetapi nilai sebenarnya dari laporan keuangan terletak pada kenyataanya bahwa laporan keuangan dapat digunakan untuk membantu meramalkan keuntungan dan deviden di masa depan. Dari sudut pandang seorang investor, meramalkan masa dapan adalah hakikat dari analisis laporan keuangan. Sedangkan dari sudut manajemen analisis laporan keuangan akan bermanfaat baik untuk mengantisipasi kondisi-kondisi di masa depan maupun yang lebih penting lagi sebagai titik awal untuk melakukan perencanaan langkah-langkah yang akan meningkatkan kinerja perusahaan di masa depan. Rasio-rasio keuangan dirancang untuk membantu kita mengevaluasi suatu laporan keuangan (Brigham, 2006: 94).

Menurut Harahap rasio keuangan adalah angka yang diperoleh dari hasil perbandingan dari satu pos laporan keuangan dengan pos lainnya yang mempunyai hubungan yang relevan dan signifikan (berarti). Misalnya antara utang dan modal, antara kas dan total asset, antara harga pokok produksi dengan total penjualan, dan lain sebagainya. Teknik ini sangat lazim digunakan para analisis keuangan. Rasio keuangan sangat penting dalam melakukan analisis terhadap kondisi keuangan perusahaan (Harahap, 2008: 297). Rasio keuangan tersebut meliputi, rasi leverage, rasio penetapan beban tetap, rasio likuiditas, rasio aktivitas dan rasio profitabilitas (Copeland, 1992:239)

Analisis rasio ini memiliki keunggulan dibanding teknik analisis lainnya. Keunggulan

tersebut antara lain: 1)Rasio merupakan angka-angka atau ikhtisar statistik yang lebih mudah 
dibaca atau ditafsirkan, 2) Merupakan pengganti yang lebih sederhana dari informasi yang disajikan laporan keuangan yang sangat rinci dan rumit, 3) Mengetahui posisi perusahaan di tengah industri lain, 4) Sangat bermanfaat untuk bahan dalam mengisi model-model pengambilan keputusan dan model prediksi, 5) Menstandarisasi size perusahaan, 6) Lebih mudah memperbandingkan perusahaan dengan perusahaan lain yang atau melihat perkembangan perusahaan secara periodik atau time series, 7) Lebih mudah melihat tren perusahaan serta melakukan prediksi di masa yang akan datang (Harahap, 2008: 298). Disamping keunggulan yang dimiliki analisis rasio, teknik ini juga memiliki beberapa keterbatasan yang harus disadari sewaktu penggunaannya agar kita tidak salah dalam penggunaannya. Adapun keterbatasan analisis rasio adalah: 1) Kesulitan dalam memilih rasio yang tepat yang dapat digunakan untuk kepentingan pemakainya, 2) Keterbatasan yang dimiliki akuntansi atau laporan keuangan juga menjadi keterbatasan teknik ini, seperti (bahan penghitung rasio atau laporan keuangan itu banyak mengandung taksiran atau jagment yang dapat dinilai bias atau subyektif, nilai yang terkandung di dalam laporan keuangan dan rasio adalah perolehan (cost) bukan harga pasar, klasifikasi dalam laporan keuangan dapat berdampak pada angka rasio, metode pencatatan dalam standar akuntansi bisa diterapkan berbeda oleh perusahaan yang berbeda), 3) Jika data untuk menghitung rasio atau laporan keuangan tidak tersedia, akan menimbulkan kesulitan menghitung rasio, 4) Sulit jika data yang tersedia tidak sinkron, 5) Dua perusahaan dibandingkan bisa saja teknik dan standar akuntansi yang dipakai tidak sama. Oleh karena jika dilakukan perbandingan bisa menimbulkan kesalahan (Harahap, 2008: 298-299)

\section{Obligasi Syariah}

Obligasi syariah (sukuk) merupakan bentuk jamak dari kata sakk yang memiliki arti sama dengan sertifikat atau note. Konsep sukuk yang merupakan konsep pemindahan kewajiban pembayaran sudah pernah dilakukan dalam masa abad pertengahan di Kawasan Timur Tengah. Ada juga definisi sukuk menurut Accounting and Auditng Organization For Islamic Financial Institution (AAOFI), sukuk adalah sertifikat dengan nilai yang sama dengan bagian atau seluruhnya dari kepemilikan harta berwujud, untuk mendapatkan hasil dan jasa di dalam kepemilikan aset dari proyek tertentu atau aktivitas investasi khusus, sertifikat ini berlaku 
setelah menerima nilai sukuk, di saat jatuh tempo dengan menerima dana seutuhnya sesuai dengan tujuan sukuk tersebut (Bahrian: 2003, 297 dalam Roikhon). Dalam hal pembiayaan obligasi syariah adalah untuk membiayai kegiatan usaha, maka ikatan yang timbul dalam penerbitan obligasi tersebut juga harus memenuhi akad mudharabah dan akad ijarah atau sewa sebagai salah satu cara yang disahkan oleh syariah (Yuliana: 2010, 153).

Berdasarkan pada keputusan Ketua Badan Pengawas Pasar Modal dan Lembaga Keuangan (BAPEPAM-LK) No. 130/BL/2006, sukuk didefinisikan sebagai efek syariah berupa sertifikat atau bukti kepemilikan yang bernilai sama dan mewakili bagian penyertaan yang tidak terpisahkan atau tidak terbagi atas: 1) Kepemilikan aset berwujud tertentu, 2) Nilai manfaat dan jasa aset proyek tertentu atau aktiva investasi tertentu, 3) Kepemilikan atas asset proyek tertentu atau aktiva investasi tertentu. Fafwa DSN No. 41/DSN-MUI/III/2004 menyatakan obligasi syariah adalah suatu surat berharga jangka panjang berdasarkan prinsip syariah yang dikeluarkan oleh emiten kepada pemegang obligasi syariah yang mewajibkan emiten untuk membayar pendapatan kepada pemegang obligasi syariah berupa bagi hasil/margin/fee serta membayar kembali obligasi pada saat jatuh tempo. Ijarah merupakan akad pemindahan hak guna (manfaat) jasa suatu barang / jasa dalam waktu tertentu melalui pembayaran sewa, tanpa diikuti dengan pemindahan kepemilikan atas barang tersebut (Yuliana, 2010: 163)

Prinsip obligasi syariah antara lain, 1) Pembiayaan hanya untuk suatu transaksi atau suatu kegiatan usaha yang spesifik, dimana harus dapat diadakan pembukuan yang terpisah untuk menentukan manfaat yang timbul, 2) Hasil investasi yang diterima pemilik dana merupakan fungsi dari manfaat yang diterima perusahaan dari dana hasil penjualan obligasi, bukan dari kegiatan usaha yang lain, 3) Tidak boleh memberikan jaminan hasil usaha yang semata-mata merupakan fungsi waktu dari uang (time value of money), 4) Obligasi tidak dapat dipakai untuk menggantikan hutang yang sudah ada (bay al dayn bi al dayn), 5) Bila pemilik dana tidak harus menanggung rugi, maka pemilik usaha harus mengikat diri (akad jaiz), 6) Pemilik dana dapat menerima pembagian dari pendapatan (revenue sharing), dimana pemilik usaha (emiten) mengikat diri untuk membatasi penggunaan pendapatan sebagai biaya usaha, 7) Obligasi dapat dijual kembali, baik kepada pemilik dana lainnya ataupun kepada emiten (bila sesuai dengan ketentuan), 8) Obligasi dapat dijual dibawah nilai pari (modal awal) kalau 
perusahaan mengalami kerugian, 9) Perubahan nilai pasar bukan berarti perubahan jumlah hutang.

Obligasi syariah sebagai bentuk pendanaan (financing) dan sekaligus investasi (investment) memungkinkan beberapa bentuk struktur yang dapat ditawarkan untuk tetap menghindarkan pada riba. Berdasarkan pengertian tersebut, Obligasi Syariah dapat memberikan: 1) Bagi Hasil berdasarkan akad Mudharabah/ Muqaradhah/Qiradh atau Musyarakah. Karena akad Mudharabah/ Musyarakah adalah kerja sama dengan skema bagi hasil pendapatan atau keuntungan, obligasi jenis ini akan memberikan return dengan penggunaan term indicative/ expected return karena sifatnya yang floating dan tergantung pada kinerja pendapatan yang dibagihasilkan, 2) Margin/Fee berdasarkan akad Murabahah atau Salam atau Istishna atau Ijarah. Dengan akad Murabahah/ Salam/ Isthisna sebagai bentuk jual beli dengan skema cost plus basis, obligasi jenis ini akan memberikan fixed return. (Sumber http//www. zonaekis.com/obligasi syariah/Struktur Obligasi Syariah)

Huda menyatakan, terdapat beberapa alasan menggunakan dalam penggunaan Obligasi Syariah Ijarah, antara lain: a) Bentuk pendanaan yang paling sesuai untuk emiten yang memiliki dasar transaksi sewa-menyewa, b) Penggunaan dana relatif fleksibel, 3) Memberikan return yang tetap, memudahkan juga dalam transaksi di pasar sekunder, 4) Telah memiliki pedoman khusus melalui pengesahan fatwa No. 41/DSN-MUI/III/2004 (Huda \& Nasution, 2007:100). Sesuai dengan pendapat Ponjowinoto dalam buku Worksop Pasar Modal Syariah, akad ijarah adalah akad pemberian hak untuk memanfaatkan objek melalui penguasaan sementara atas pinjaman objek dengan manfaat tertentu dengan membayar imbalan kepada pemilik objek. Ijarah mirip dengan leasing namun tidak sepenuhnya mirip dengan leasing karena ijarah dilandasi adanya pemindahan manfaat tetapi tidak terjadi pemindahan kepemilikan. Hal ini didukung oleh pendapat El-Diwany "financial lease" modern berbeda karena pembayaran sewa telah diatur (orang yang menyewakan aset (lessor) tidak akan memperoleh kembali nilai aset sepenuhnya melalui pembayaran sewa, karena itu paling tidak terkena sebagian risiko dan memperoleh manfaat memiliki aset pada akhir masa penyewaan). Sehingga, memberikan pengembalian kepada pemilik sepenuhnya atas dana-dana yang diinvestasikan di dalam aset ditambah tingkat keuntungan atas aset yang disepakati sebelumnya. (El-Diwany, 2005:183). Ketentuan akad ijarah adalah sebagai berikut: 1) Berbeda dengan leasing, di samping dapat 
berupa suatu barang (harta fisik yang bergerak, tak bergerak, harta perdagangan), objek dapat pula berupa jasa (amal) yang diberikan oleh manusia atau binatang, 2) Objek, manfaat yang dipinjamkan dan nilai manfaat harus diketahui dan disepakati terlebih dahulu oleh para pihak, 3) Ruang lingkup pemakaian objek dan jangka waktu pemakaian harus dinyatakan secara spesifik, 4) Atas pemakaian objek, pemakai manfaat (penyewa) harus membagi hasil manfaat yang diperoleh dalam bentuk imbalan sewa/ upah (akar kata ijarah berarti upah), 5) Berbeda dengan leasing, secara umum cara pembayaran sewa ditentukan menurut kinerja dari objek, namun dalam hal pemakai manfaat (penyewa) yakin akan kinerja dari objek, maka pembayaran sewa dapat ditentukan menurut waktu pemakaian sehingga mirip dengan leasing, 6) Pemberi sewa haruslah pemilik mutlak, agen dari pemilik mutlak, penjaga secara alami atau legal dari objek, 7) Pemberi sewa (pemilik objek ijarah) dapat mengadakan akad jaiz untuk menjual atau menghibahkan oleh ijarah kepada pemakai manfaat (penyewa) menuntut ketentuan tertentu pada akhir dari masa sewa, 8) Dilarang melakukan akad ijarah atau akad jual beli secara sekaligus pada waktu yang sama karena akan menimbulkan akad (gharar) (Yuliana, 2010: 164165)

Dalam obligasi syariah ijarah, keuntungannya sudah dapat diketahui secara pasti sejak awal, karena sifatnya sebagai sewa atas guna barang (fee/sewa). Maka hasil investasi bersifat mendekati pasti karena merupakan imbalan sewa atau upah atas pemakaian manfaat dari objek pembiayaan. Pengembalian modal awal disamping nilai pembayaran atas penjualan objek pembiayaan pada akhir masa pembiayaan, sehingga dari imbalan sewa juga dapat diperhitungkan sebagai cicilan atas pengembalian modal awal. Cicilan ini dapat ditampung dalam suatu sinking fund pada Bank Kustodian atau Wali Amanat. Menurut ketentuan pasal 1 butir 30 UUPM, wali amanat adalah pihak yang mewakili kepentingan pemegang efek yang bersifat utang, sedangkan pihak diartikan sebagai orang perseorangan, peruasahaan, usaha bersama, asosiasi atau kelompok yang terorganisasi. (Huda \& Nasution, 2007: 75)

\section{Gambar 1}

Skema Obligasi Syariah Ijarah 


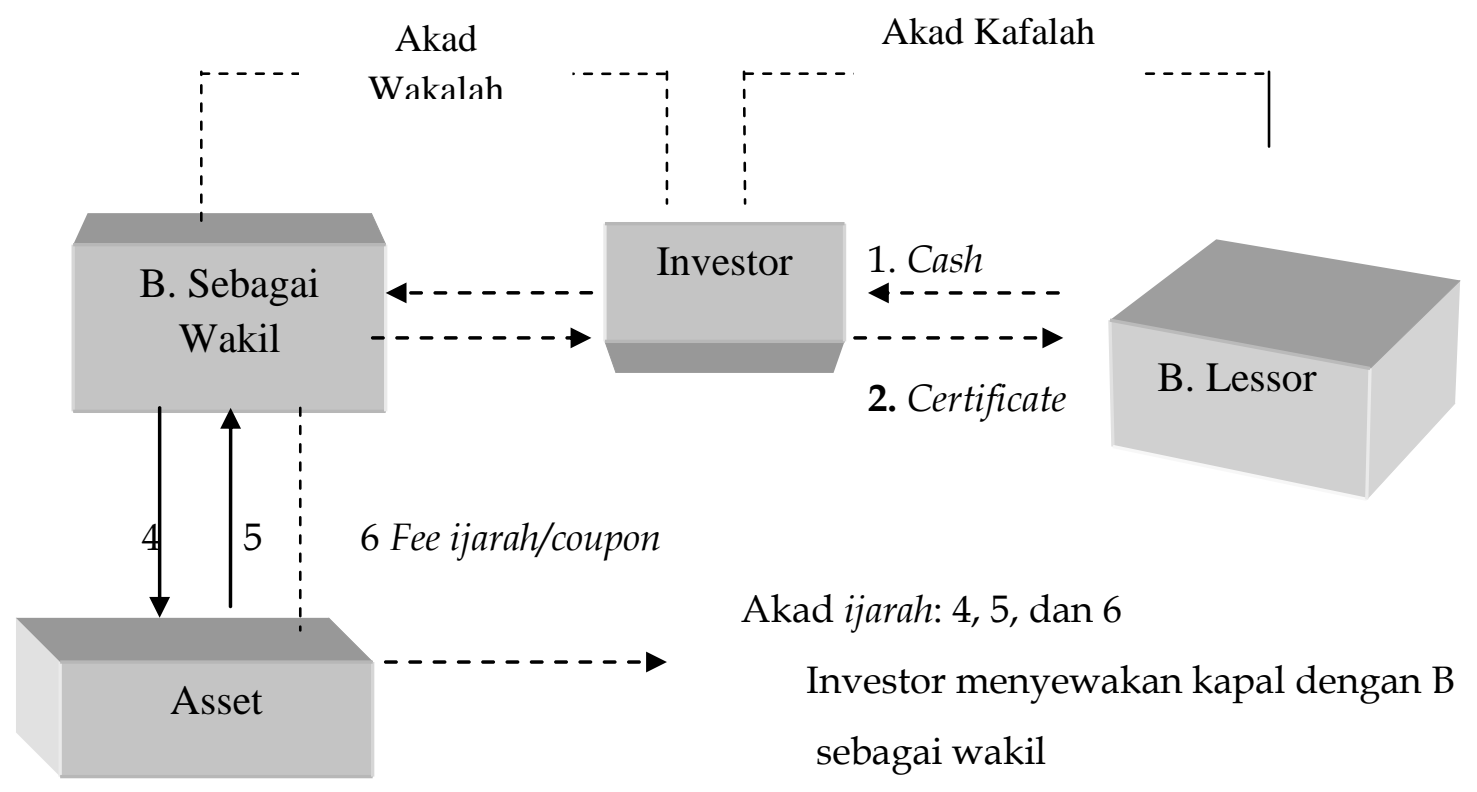

Sumber: (Gunawan dalam Yuliana, 2010:166)

Imbalan hasil yang akan diberikan kepada para pemegang obligasi syariah ijarah tersebut didapatkan dari hasil sewa dengan tingkat fee ijarah tetap. Fee ijarah ini diperoleh dari penyewaan tempat dan telah ditentukan sebelumnya. Bukan tergantung dari bagi hasil sebagaimana obligasi mudharabah. Obligasi ijarah menggunakan akad sewa, sehingga besar return yang diberikan sama sepanjang waktu obligasi berlaku.

\section{METODE PENELITIAN}

Lokasi penelitian berada pada perusahaan-perusahaan yang menerbitkan obligasi syariah ijarah tepatnya di PT Kustodian Sentral Efek Indonesia. Penelitian ini merupakan jenis penelitian kuantitatif. Pendekatan dalam penelitian ini yaitu menggunakan pendekatan korelatif, yang mana dalam penelitian ini menghubungkan antara variabel independen berupa kinerja keuangan perusahaan (faktor laverage, rasio penutupan bunga, rasio lancar, ROA, asset turnover) dengan variabel dependen berupa penetapan tingkat sewa obligasi syariah ijarah. Kemudian diuji dengan menggunakan analisis statistik.

Pengambilan data dengan cara dokumentasi. Terdapat 36 Populasi (36 obligasi ijarah di Indonesia). Sedangkan sampel pada penelitian ini adalah 30 obligasi syariah ijarah, yakni obligasi syariah ijarah pada periode 11 April 2005- 9 Juli 2010. Teknik pengambilan sampel 
menggunakan nonprobability sampling artinya teknik pengambilan sampel yang tidak memberi peluang / kesempatan sama bagi setiap unsur atau anggota populasi untuk dipilih menjadi sampel. Teknik sampling yang digunakan dalam penelitian ini adalah porposive sampling, teknik ini merupakan teknik penentuan sampel dengan pertimbangan tertentu. Kriteria sampel dalam penelitian ini: 1) Obligasi syariah ijarah dengan periode tahun 2005-2010, 2) Emiten obligasi syariah ijarah yang terdaftar pada Bursa Efek Indonesia / perusahaan penerbitkan obligasi syariah ijarah sudah go publik di Bursa Efek Indonesia, 3) Emiten Obligasi syariah ijarah yang menerbitkan laporan keuangan 5 tahun sebelum periode penelitian

\section{Tabel 1}

Sampel Penelitian

\begin{tabular}{|c|c|c|}
\hline Nama Perusahaan & $\begin{array}{c}\text { Listing Menjadi } \\
\text { Emiten } \mathrm{Ob} . \\
\text { Syariah }\end{array}$ & Nama Obligasi \\
\hline Indosat & $\begin{array}{l}22 \text { June } 2005 \\
30 \text { May } 2007 \\
10 \text { April } 2008 \\
09 \text { December } 2009 \\
09 \text { December } 2009\end{array}$ & $\begin{array}{l}\text { Obligasi Syariah Ijarah Indosat Tahun } 2005 \\
\text { Sukuk Ijarah Indosat II Tahun } 2007 \\
\text { Sukuk Ijarah Indosat III Tahun } 2008 \\
\text { Sukuk Ijarah Indosat IV Tahun } 2009 \text { Seri A } \\
\text { Sukuk Ijarah Indosat IV Tahun } 2009 \text { Seri B }\end{array}$ \\
\hline PLN & $\begin{array}{l}\text { 22 June } 2006 \\
11 \text { July } 2007 \\
12 \text { January } 2009 \\
12 \text { January } 2009 \\
13 \text { January } 2010 \\
13 \text { January } 2010 \\
\text { 09 July } 2010 \\
\text { 09 July } 2010\end{array}$ & $\begin{array}{l}\text { Obligasi Syariah Ijarah PLN I Tahun } 2006 \\
\text { Sukuk Ijarah PLN II Tahun } 2007 \\
\text { Sukuk Ijarah PLN I Tahun } 2009 \text { Seri A } \\
\text { Sukuk Ijarah PLN III Tahun } 2009 \text { Seri B } \\
\text { Sukuk Ijarah PLN IV Tahun } 2010 \text { Seri A } \\
\text { Sukuk Ijarah PLN IV Tahun } 2010 \text { Seri B } \\
\text { Sukuk Ijarah PLN V Tahun } 2010 \text { Seri A } \\
\text { Sukuk Ijarah PLN V Tahun } 2010 \text { Seri B }\end{array}$ \\
\hline Aneka Gas Industri & 09 July 2008 & Sukuk Ijarah Aneka Gas Industri I Tahun 2008 \\
\hline Berlian Laju Tanker & $\begin{array}{l}06 \text { July } 2007 \\
29 \text { May } 2009\end{array}$ & $\begin{array}{l}\text { Sukuk Ijarah Berlian Laju Tanker Tahun } 2007 \\
\text { Sukuk Ijarah Berlian Laju Tanker II Th } 2009\end{array}$ \\
\hline
\end{tabular}




\begin{tabular}{|c|c|c|}
\hline & 29 May 2009 & $\begin{array}{l}\text { Seri A } \\
\text { Sukuk Ijarah Berlian Laju Tanker II Th } 2009 \\
\text { Seri B }\end{array}$ \\
\hline $\begin{array}{l}\text { Bakrieland } \\
\text { Development }\end{array}$ & $\begin{array}{l}09 \text { july } 2009 \\
09 \text { July } 2009\end{array}$ & $\begin{array}{l}\text { Sukuk Ijr I Bakrieland Development Th } 2009 \\
\text { Seri A } \\
\text { Sukuk Ijr I Bakrieland Development Th } 2009 \\
\text { Seri B }\end{array}$ \\
\hline Mitra Adhi Perkasa & $\begin{array}{l}09 \text { December } 2009 \\
17 \text { December } 2009\end{array}$ & $\begin{array}{l}\text { Sukuk Ijarah Mitra Adiperkasa I Tahun } 2009 \\
\text { Seri A } \\
\text { Sukuk Ijarah Mitra Adiperkasa I Tahun } 2009 \\
\text { Seri B }\end{array}$ \\
\hline Matahari & $\begin{array}{l}15 \text { April } 2009 \\
15 \text { April } 2009\end{array}$ & $\begin{array}{l}\text { Sukuk Ijr Matahari Putra Prima II Th } 2009 \text { Seri } \\
\text { A } \\
\text { Sukuk Ijr Matahari Putra Prima II Th } 2009 \text { Seri } \\
\text { B }\end{array}$ \\
\hline Metrodata Electronics & 04 July 2008 & $\begin{array}{l}\text { Sukuk Ijarah Metrodata Electronics I Tahun } \\
2008\end{array}$ \\
\hline Pupuk Kaltim & 07 December 2009 & $\begin{array}{l}\text { Sukuk Ijarah Pupuk Kalimantan Timur I } \\
\text { Tahun } 2009\end{array}$ \\
\hline Salim Inomas & 02 December 2009 & $\begin{array}{l}\text { Sukuk Ijarah Salim Ivomas Pratama I Tahun } \\
2009\end{array}$ \\
\hline Summarecon Agung & June 2008 & $\begin{array}{l}\text { Sukuk Ijarah Summarecon Agung I Tahun } \\
2008\end{array}$ \\
\hline $\begin{array}{l}\text { Titan Petrokimia } \\
\text { Nusantara }\end{array}$ & 03 June 2010 & $\begin{array}{l}\text { Sukuk Ijarah Titan Petrokimia Nusantara I Th } \\
2010\end{array}$ \\
\hline Apexindo Pratama & 11 April 2005 & $\begin{array}{l}\text { Obligasi Syariah Ijarah Apexindo Pratama } \\
\text { Duta I Tahun } 2005\end{array}$ \\
\hline Riky putra globalindo & 13 July 2005 & $\begin{array}{l}\text { Obligasi Syariah Ijarah Ricky Putra } \\
\text { Globalindo Tahun } 2005\end{array}$ \\
\hline
\end{tabular}

Sumber: diolah dari http//www.ksei.co.id/sukuk 
Data yang digunakan dalam penelitian ini merupakan data sekunder, yang berupa data: 1) Penetapan tingkat sewa obligasi syariah ijarah, 2) Emiten obligasi syariah ijarah, 3) Laporan keuangan emiten/ perusahaan penerbit obligasi syariah ijarah. Model analisis data yang digunakan adalalah dengan menggunakan regresi linier.

PAPARAN DAN PEMBAHASAN DATA HASIL PENELITIAN

Uji Regresi

Tabel 3

Uji Regresi Secara Parsial

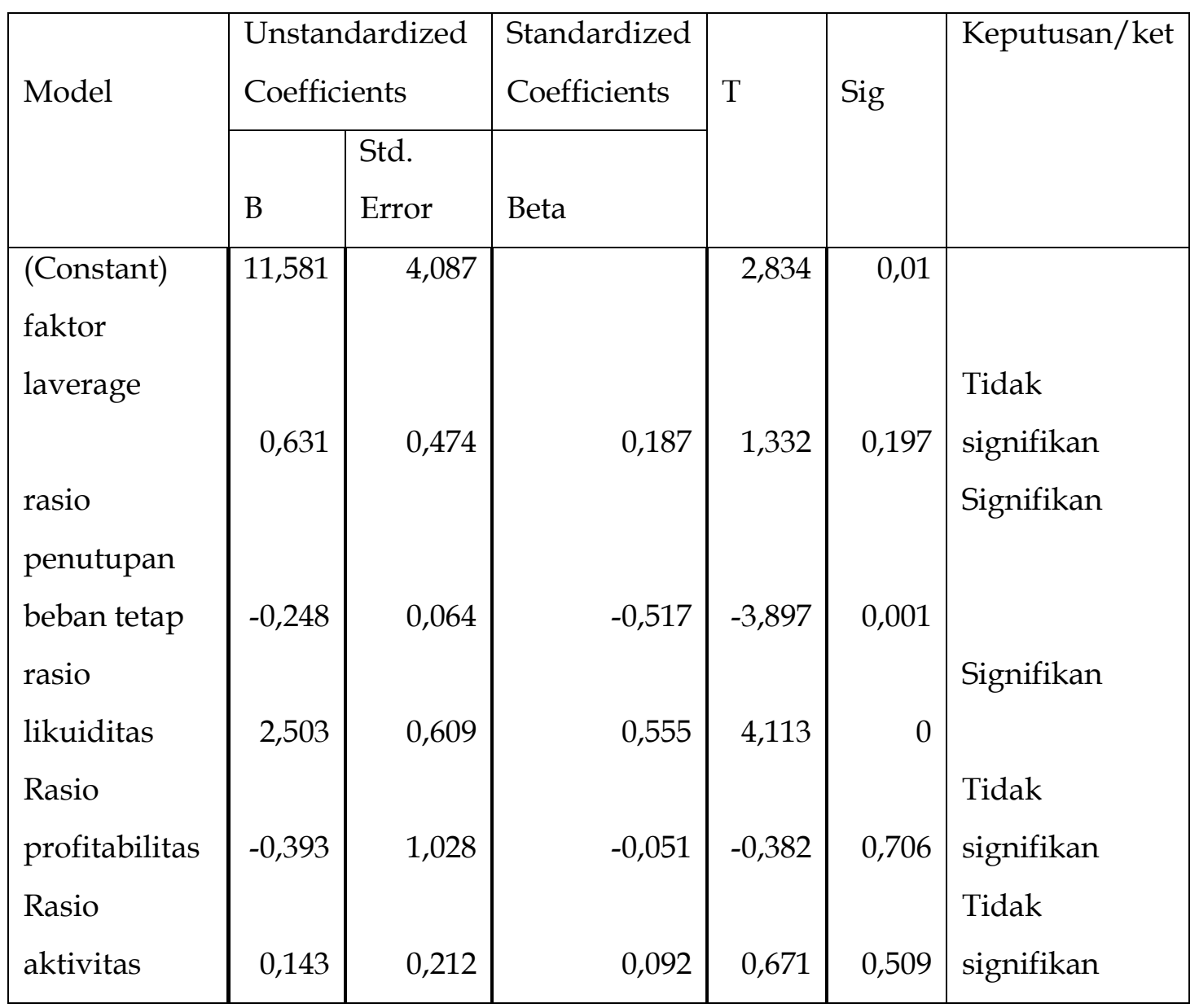

Sumber: data skunder diolah peneliti

Berdasarkan pada data hasil regresi yang ditunjukkan tabel di atas, dapat diperoleh persamaan regresi sebagai berikut:

$Y=11,581+0,631 X 1-0,248 X 2+2,503 X 3-0,393 X 4+0,143 X 5$ 
Berdasarkan persamaan di atas dapat diartikan bahwa: Pertama, Konstanta. Nilai konstanta dari persamaan regresi ini sebesar 11,581 menyatakan bahwa jika tidak ada faktor leverage, rasio penutupan beban tetap, rasio likuiditas, rasio profitabilitas, dan rasio aktivitas maka penetapan tingkat sewa obligasi syariah ijarah sebesar 11,581. Kedua, Koefisien variabel X1 faktor leverage sebesar 0,631 menunjukkan bahwa apabila faktor laverage naik sebesar 0,631 maka penetapan tingkat sewa obligasi syariah ijarah akan naik sebesar 0,631 satuan, dalam hal ini faktor lain yang mempengaruhi penetapan tingkat sewa obligasi syariah ijarah dianggap konstan. Ketiga, Koefisien variabel X2 rasio penutupan beban tetap sebesar -0,248 menunjukkan bahwa apabila rasio penutupan beban tetap naik sebesar -0,248 maka penetapan tingkat sewa obligasi syariah ijarah akan turun sebesar -0,248 satuan, dalam hal ini faktor lain yang mempengaruhi penetapan tingkat sewa obligasi syariah ijarah dianggap konstan. Keempat, Koefisien variabel X3 (rasio likuiditas) sebesar 2,503 menunjukkan bahwa apabila rasio lancar naik sebesar 2,503 maka penetapan tingkat sewa obligasi syariah ijarah akan naik sebesar 2,503 satuan, dalam hal ini faktor lain yang mempengaruhi penetapan tingkat sewa obligasi syariah ijarah dianggap konstan.

Kelima, Koefisien variabel X4 rasio profitabilitas sebesar -0,393 menunjukkan bahwa apabila rasio profitabilitas naik sebesar -0,393 maka penetapan tingkat sewa obligasi syariah ijarah akan turun sebesar -0,393 satuan, dalam hal ini faktor lain yang mempengaruhi penetapan tingkat sewa obligasi syariah ijarah dianggap konstan. Dan ke-enam, Koefisien variabel X5 (rasio aktivitas) sebesar 0,143 menunjukkan bahwa apabila rasio aktivitas naik sebesar 0,143 maka penetapan tingkat sewa obligasi syariah ijarah akan naik sebesar 0,143 satuan, dalam hal ini faktor lain yang mempengaruhi penetapan tingkat sewa obligasi syariah ijarah dianggap konstan.

\section{Hasil Pengujian Hipotesis}

Uji t atau uji hipotesis secara parsial

\section{Tabel 4}


Hasil Perhitungan Uji Regresi Secara Parsial

\begin{tabular}{|l|r|r|l|l|}
\hline Variabel & t hitung & \multicolumn{1}{l|}{ Sig. } & Keterangan & Keputusan \\
\hline Faktor Laverage & 1,332 & 0,197 & Probabilitas / sig $>5 \%$ & $\mathrm{H}_{0}$ diterima \\
\hline $\begin{array}{l}\text { Rasio Penutupan Beban } \\
\text { Tetap }\end{array}$ & $-3,897$ & 0,01 & Probabilitas / sig < 5\% & $\begin{array}{l}\mathrm{H}_{1} \\
\text { diterima }\end{array}$ \\
\hline Rasio Likuiditas & 4,113 & 0,000 & Probabilitas / sig < 5\% & $\begin{array}{l}\mathrm{H}_{1} \\
\text { diterima }\end{array}$ \\
\hline Rasio Profitabilitas & $-3,382$ & 0,706 & Probabilitas / sig $>5 \%$ & $\mathrm{H}_{0}$ diterima \\
\hline Rasio aktivitas & 0,671 & 0,509 & Probabilitas / sig $>5 \%$ & $\mathrm{H}_{0}$ diterima \\
\hline
\end{tabular}

Sumber: data skunder diolah peneliti

Dari Hasil uji t di atas dapat disimpulkan bahwa secara individual (parsial) variabel yang berpengaruh terhadap penetapan tingkat sewa obligasi syariah ijarah adalah variabel rasio penutupan bunga, dan rasio lancar. Hal ini disebabkan nilai signifikansi dari rasio penutupan beban tetap sebesar 0,01, dan rasio lancar sebesar 0,000 dengan tingkat $a=5 \%$ pada signifikansi $\mathrm{p}<0,05$. Sedangkan variabel faktor laverage, rasio profitabilitas dan rasio aktivitas tidak berpengaruh terhadap penetapan tingkat sewa obligasi syariah ijarah karena pada signifikansi $\mathrm{p}>0,05$.

Tabel 5

Hasil Uji Hipotesis Kedua

\begin{tabular}{|l|l|}
\hline Variabel & Beta \\
\hline Faktor laverage &, 187 \\
Rasio penutupan beban &,- 517 \\
tetap &, 555 \\
Rasio likuiditas &,- 051 \\
Rasio profitabilitas &, 092 \\
Rasio aktivitas & \\
\hline
\end{tabular}

Sumber: data sekunder yang diolah peneliti

Pengujian hipotesis yang kedua untuk menentukan variabel bebas yang dominan mempengaruhi penetapan tingkat sewa obligasi syariah ijarah. Pengujian ditentukan dengan melihat pada nilai standartdized Coefficients atau beta pada masing-masing variabel bebas yang 
diteliti. Dari tabel di atas dapat dilihat variabel yang mempunyai beta paling tinggi adalah variabel rasio likuiditas sebesar 0,555. Nilai ini menunjukkan bahwa rasio likuiditas mempunyai pengaruh yang dominan terhadap penetapan tingkat sewa obligasi syariah ijarah. Hipotesis ketiga yang menyatakan bahwa faktor leverage merupakan variabel yang paling berpengaruh terhadap harga penetapan tingkat sewa tidak terbukti.

\section{Pembahasan Hasil Penelitian}

Dan jika dilihat dari uji parsial menyatakan hanya ada dua variabel yang berpengaruh secara signifikan terhadap penetapan tingkat sewa obligasi syariah ijarah, kedua variabel tersebut adalah, rasio penutupan beban tetap, dan rasio likuiditas. Rasio lancar merupakan ukuran yang paling umum digunakan untuk mengetahui kesanggupan perusahaan dalam memenuhi kewajiban jangka pendek. Oleh karena itu rasio ini untuk melihat seberapa jauh tuntutan dari kreditur mengenai jangka pendek dipenuhi oleh aktiva yang diperkirakan menjadi uang tunai dalam periode yang sama dengan jatuh tempo. Seperti halnya obligasi syariah yang dikeluarkan oleh PT. Matahari Putra Prima memberikan pembayaran sewa setiap tiga bulan sekali. Seperti Analisis rasio ini dapat digunakan untuk memperkirakan potensi resiko yang akan dihadapi dikaitkan dengan adanya jaminan kelangsungan pembayaran beban tetap dan pengembalian pokok pinjamannya (Djarwanto, 1984 Dalam Amrullah, 2007: 20). Teori tersebut sangat singkron terhadap hasil uji parsial yang menunjukkan bahwa variabel rasio penutupan beban tetap berpengaruh signifikan terhadap penetapan tingkat sewa pada obligasi syariah ijarah

Sedangkan rasio yang tidak berpengaruh secara signifikan terhadap penetapan tingkat

sewa obligasi syariah ijarah di Indonesia adalah profitabilitas. Rasio ini menunjukkan kemampuan dasar untuk menghasilkan laba (basic earning power-BEP), dalam hal ini walaupun laba perusahaan banyak akan tetapi uporsi hutang yang dimiliki lebih banyak dari pada modal yang dimiliki perusahaan dan juga aktiva untuk menjamin hutangnya sedikit maka seorang investor juga masih meragukannya ketika akan meninjamkan atau membeli obligasi syariah karena hal tersebut sangat erat kaitannya dengan bagaimana keadaan sebuah perusahaan dalam menjamin hutangnya, atau tingkat risiko yang akan dihadapi. Selain rasio profitabilitas terdapat pula rasio keuangan yang tidak berpengaruh secara signifikan dalam penelitian ini 
yakni rasio aktivitas, hal tersebut dikarenakan Rasio aktivitas mengukur perputaran dari seluruh aktiva perusahaan rasio ini dihitung dengan membagi penjualan dengan total aktiva.

\section{Rasio Likuiditas Dominan Pengaruhnya}

Rasio likuiditas dominan mempengaruhi penetapan tingkat sewa obligasi syariah ijarah. Pengujian ditentukan dengan melihat pada nilai standartdized Coefficients atau beta pada masing-masing variabel bebas yang diteliti. Dari tabel di atas dapat dilihat variabel yang mempunyai beta paling tinggi adalah variabel rasio lancar sebesar 0,555. Nilai ini menunjukkan bahwa rasio lancar mempunyai pengaruh yang paling dominan terhadap penetapan tingkat sewa obligasi syariah ijarah. Dalam penelitian ini mendukung penelitian Monica Krisnilasari (2007,) yang hasil penelitiannya menunjukkan variabel kinerja keuangan (likuiditas) memiliki pengaruh positif signifikan terhadap perubahan harga obligasi (return obligasi). Rasio likuiditas merupakan indikator tunggal terbaik sampai sejauh mana klaim dari kreditor jangka pendek telah ditutupi oleh aktiva-aktiva yang diharapkan dapat diubah menjadi kas dengan cepat.

\section{PENUTUP}

Kesimpulan

Berdasarkan hasil dari analisis data dan pembahasan maka dapat diambil kesimpulan sebagai berikut:

Pertama, hasil analisis regresi dengan uji t (uji parsial) menunjukkan bahwa secara individual (parsial) variabel yang berpengaruh terhadap penetapan tingkat sewa obligasi syariah ijarah di Indonesia adalah rasio penutupan beban tetap, dan rasio likuiditas. Kedua, Variabel rasio likuiditas mempunyai pengaruh dominan terhadap penetapan tingkat sewa obligasi syariah ijarah di Indonesia karena memiliki beta yang paling tinggi di banding dengan beta variabel yang lainnya sebesar 0,555.

\section{Saran}

Dengan melihat hasil penelitian maka penulis memberikan saran yang mungkin akan berguna baik untuk investor maupun pihak-pihak lain. Saran-saran tersebut sebagai berikut: 
Pertama, Bagi peneliti selanjutnya diharapkan menambah objek penelitian yakni obligasi mudharabah, menambah variabel penelitian, dan menambah periode penelitian. Hal ini perlu dilakukan agar hasil yang diinginkan lebih memuaskan. Kedua, bagi calon investor sebelum berinvestasi pada obligasi syariah ijarah hendaknya melihat kredibilitas dan kemampuan emiten dalam mencapai kinerja keuangannya.

DAFTAR PUSTAKA

Budi Setiawan, Aziz. Tt. Obligasi (Sukok) Syariah: Alternatif Pendanaan Korporasi 
Bodie, Zvi dan Alex Kene dan Alan J. 2006. Marcus. Investment. Penerjemah Zuliani Dalimunthe. Jakarta: Salemba Empat

Brigham, Eugene F \& Joel F. Houston. 2006. Dasar-Dasar Manajemen Keuangan. Penerjemah: Ali Akbar Yulianto. Jakarta: Salemba Empat

El-Diwany, Tareka. 2005. The Problem With Interest. Penerjemah Amdiah Amir. Jakarta: Media Eka Sarana

Fahmi, Irham. 2006. Analisis Investasi Persepektif Ekonomi dan Politik. $\quad$ Bandung: PT Refika Aditama.

Gemala, Dewi. 2006. Aspek-Aspek Hukum dalam Perbankan dan Perasuransian Syariah di Indonesia. Jakarta: Penerbit Kencana

Gretta \& Theresa Tanoto \& Basco Carvola \& Anna Ellly. Penerjemah Margareta Sumaryati. 2004. Ilmu Makro ekonomi. Jakarta: PT Media Global Edukasi

Fraser, L Lyn \& Ormiston Aileen. 2008. Memahami Laporan Keuangan. Penerjemah Ali Mutasowifin.. Indonesia: PT Macanan Jaya Cemerlang

H. Achsien, Inggi. 2003. Investasi Syariah Di Pasar Modal “ Menggagas Konsep dan Praktek Manajemen Portofolio Syariah". Jakarta: PT Gramedia Pustaka Utama

Harris Muhajir, M. 2008. “Analisis Kointegrasi: Keterkaitan Jakarta Islamic Indeks Dengan IHSG dan SBI Di Bursa Efek Jakarta”. Tesis. Semarang: FE-UNDIP

Hasan, Iqbal. 2002. Pokok-Pokok Metodologi Penelitian \& Aplikasi. Bogor: Ghalia Indonesia.

Hasan, Iqbal. 2006. Analisis Data Penelitian dengan Statistik. Jakarta. Bumi Aksara

Huda, Nurul dan Mustafa Edwin Nasution. 2007. Investasi Pada Pasar Modal Syariah. Jakarta: Kencana Prenada Media Group.

Nazwar, Chairul. 2008. Analisis Pengaruh Variabel Makro ekonomi Terhadap Return Saham Syariah Di Indonesia. Jurnal Perencanaan \& Pengembangan Wilayah, Vol.4, No.1

Nopirin. 2000. Ekonomi Moneter. Yogyakarta: BPFE

Pontjowinoto, Iwan. 2007. “Hasil Penelitian Obligasi Syariah Korporasi'. Disertasi. UNPAD Roikhon. 2009. Perkembangan Transaks Syariah Muamalah Pada Sukuk/SBSN di Indonesia dan Malaysia Konsep Kaffah Thinking. National Seminar On Sharia Transaction Research. Jakarta: UIN Syarif-FSH

Sugiono, 2008. Metode Penelitian Bisnis. Bandung: Alfa Beta

Sunarsih. 2008. "Potensi Obligasi Syariah Sebagai Sumber Pendanaan Jangka Menengah dan Panjang bagi Perusahaan di Indonesia". Jurnal Asy-Syir'ah Vol. 42 No. I 2008 
Suriadi, Irwan. 2007. “Faktor-Faktor Yang Menentukan Rating Obligasi Indonesia”. Tesis. Yogyakarta: FE-UGM

Sutedi, Ardian. 2009. Aspek Hukum Obligasi dan Sukuk. Jakarta: Sinar Grafika

Harahap, Sofyan Syafri. 2008. Analisis Kritis atas Laporan Keuangan. Jakarta: PT Raja Grafindo Persada

Widjaja, Gunawan dan Jono. 2006. Penerbitan Obligasi dan Peran Serta Tanggung Jawab Wali Amanat dalam Pasar Modal. Jakarta: Kencana Prenada Media Grroup

Weston, J. Fred \& Thomas E. Copeland. Penerjemah A. Jaka Wasana \& Kibrandoko.1995. Manajemen Keuangan. Jakarta: Binarupa Aksara

Yuliana, Indah. 2010. Investasi Produk Keuangan Syariah. Malang: UIN- MALIKI Press

Yuliana, Indah. 2008. “Analisis Pengaruh Inflasi dan Tingkat Suku Bunga SBI Terhadap Return Obligasi Syariah Mudharabah dan Ijarah di Indonesia". Jurnal Ulul Albab Vol 9. No. Hal 121- 141

http//www.blogspot.com//investasi syariah/ Perkembangan Syariah Dunia

http//www.google.com/obligasi syariah/fatwa MUI

http//www/ / halalguide.info/Obligasi Syariah Ijarah/fatwa MUI

http//ksei.co.id/sukuk

http//www.wikipedia.com/agama di Indonesia

http//www.zonaekis.com/mengintip peluang obligasi syariah 
